THURSDAY, SEPTEMBER 22, I88I

\section{EGYPTIAN EXCAVATIONS AND MUMMIES}

THE recent excavations in Egypt have been productive of great results to archæology and the history of Egypt. One site, which has yielded unexpected additions to the early period of the country, has been excavated on scientific principles under the direction of M. Maspero, the present superintendent or director of the Archæological Department. It is his intention to open the whole group of unexplored pyramids, in order to find the sequence of monarchs of whom they were the sepulchres, and to discover any inscriptions with which they may have been decorated. An examination of the whole group of pyramids indeed was formerly made by J. Shay Perring, C.E., at the expense of Col. Howard Vyse, who spent a fortune in pyramidal researches; but the excavations of Perring were chiefly devoted to the examination of three great pyramids of Gizeh, those of Cheops, Chephren, and Mycerinus, and although he examined the whole group in the scientific manner of an engineer, by some fatality he appears not to have penetrated into the interior of the smaller ones, which are now in process of examination by M. Maspero. The conviction which that savant has arrived at is that these pyramids are arranged in symmetrical groups, each group holding the remains of the monarchs who followed each other in chronological succession. The group just discovered consists of three pyramids at Sakkara, of small dimensions, lying to the N. and E. of the step-shaped pyramid, and on the road to the Serapeum, the sepulchres of three monarchs of the sixth dynasty, Ra-meri or Mira, whose name was Pepi or Phiops, a king who is said to have reigned 100 years all but an hour ; his successor, Merienra, named Har-em-saf, or Ta-em-saf, and a king called Una. They seem all to have been constructed on the same principle, having inclined entrances leading to sepulchral chambers with pointed roofs, the walls of the passages and chambers covered with hieroglyphs coloured green, the ceilings of the sepulchral chambers with pointed roofs on which were stars in white upon a black ground, indicative of the hours of the night. The inscriptions of these chambers are of interest purely mythological, no historical fact or allusion being mentioned in them, but their contents consisting of prayers similar to those in the Book of the Dead, or Ritual, and chiefly referring to the myth of Osiris and Hades, especially the identification of the kings with Osiris as the son of Nut and Seb, and his following the course of the constellation Orion, rising and setting with that constellation, allied with the star Sebt, or Sothis, and the progress of the king to the Aahlu or Egyptian Elysium, and in the account of the Island of the Fields of Ho-tep, or Peace, recalling to mind Eden, mention is made of a tree of life. In the Pyramid of Pepi, the Phiops of the sixth dynasty, who is said by the history of Manetho to have reigned Ioo years all but an hour, and who must consequently have ascended the throne quite a boy, was found the remains of a sarcophagus of black and white granite of unfinished work, which had been broken, and another in the south-east corner of the chamber of the same material, which had been let into the masonry. In the vicinity of this sarcophagus on the west side between VoL. XxIv. -No. 621 this and the wall was found amidst a heap of rubbish remains of dresses and mummy bandages varying from yellow to dark brown of extreme fineness; of the mummy itself an embalmed hand in good condition was only found, and even this may be considered remarkable, as the bodies of the earlier period were only dried, and not embalmed, and generally fall to pieces when exposed to air. The pyramid was indeed small, considering the long reign of Pepi. The Pyramid of Merienra, or Har-em-saf, which resembled in general character that of Pepi or Phiops, had two sarcophagi of red granite close to one another, the cover of one removed and hidden under blocks of stone. The other held a body mummied, which was that of the king; it had been anciently plundered of its ornaments, but embalmed with the greatest care, the skin well preserved, the traits of the countenance distinct, the eyes closed, the end of the nose fallen in, the stature of medium height, and the limbs youthful. This king was the successor of Phiops. The third pyramid of the group was of Noferkara or Nephercheres, but no details of the inscriptions have as yet been published, although they probably refer to the Osiris myth, like the others. The details of the size of coffins and mummies of this pyramid are still wanting. Each pyramid had a special name: that of Pepi was called Mennefer, that of Ha-rem-saf was Shanefer, that of Noferkara also Mennefer. Compared with the great Pyramids of Gizeh, they are far inferior, but the inscriptions in them offer an interest greater than that of the plain Gizeh Pyramids. The only question is whether the mummies found in them are contemporaneous with the sixth dynasty, which appears most probable, or subsequent usurpations, of which there is no monumental or inscribed evidence.

The next remarkable discovery is that of the thirtynine mummies, several of kings, in a subterraneous well or pit not very far from the edifice of the Deir-el-Bahari. This remarkable structure, consisting of a temple on a platform with chambers let into the solid rock, had been published by Marriette Pasha, and had been suspected by Brugsch Bey to be the site of the sepulchres of the early monarchs of the eighteenth dynasty. The temple itself had been commenced by the queen Hatasu or Hasheps, daughter of Thothmes I. and wife of Thothmes II., and its sculptures commemorated the expedition made by that queen to Punt or Somali, the treasures brought from thence in gold, silver, frankincense, besides trees of that material, besides giraffes, cynocephali, large dogs. Besides which they give representations of the inhabitants and of the Egyptian fleet which descended the Red Sea on the voyage of amity or discovery promoted by the Egyptian queen.

In the well or pit of the Deir-el-Bahari, which was formed of bricks of conical shape stamped with inscriptions, on which could be traced the titles of the high priest of Amen-ra thus used by the monarchs of the twentyfirst dynasty, were found the coffins, mummies, and other objects which appear to have been there deposited in the reign of Herhor, first monarch of the twenty-first dynasty, and of another king, Panetem or Pinotem, of the same dynasty. The cause of the removal of the mummies deposited in the Theban sepulchres, such as the El Assasif and the Biban-el-Molook, is stated on some of the wraps of the mummies to have been the apprehension 
of a foreign invasion, and that possibly of the Assyrians, whose arms had made great progress in Central Asia. According to Brugsch Bey the twenty-second dynasty was Assyrian, and he identifies the name of the monarch with that race; but at all events they were never Assyrian monarchs, such names as Shashanq or Shishak, Namrutha or Nimrod, not having been found in the Assyrian annals, although Uasarkan or Sargon, and Takelloth or Diglath may correspond with Assyrian kings.

From the El Assasif had been removed the mummy of Taakan, also known as Skanenra, which was formerly deposited at the Drah Abu-el-Neggah with its three inscribed coffins, and which was intact at the time of Rameses IX. about B.C. II50. It was in his reign that the quarrel of the Egyptian kings with the Shepherd Kings commenced, and he is mentioned in the celebrated Sallier Papyrus. The mummy of Aahmes or Amosis I. in three plain cases was also found amongst the coffins, but it is not known where this king was buried; as he succeeded Skanenra, his tomb was probably somewhere in the vicinity. The mummy of Aahmes Nefertari was also found, it is said, in three cartonages with paintings on a white ground. Another queen, Aahhotep, daughter of the King Aahmes, was also found, and it will be recollected that this was the name of the queen whose mummy and coffins, and gold and silver jewellery, and arms were discovered by fellaheen at the Biban-el-Molook, a few feet below the surface. She was wife of Kames and mother of Aahmes, while the queen of the Deir-el-Bahari was the wife of Amenophis I. The mummy of Amenhotep I. or Amenophis was found in a wonderful state of preservation, painted and varnished, and with wreaths of flowers so exquisitely preserved that they retain all their colour like recent flowers kept and pressed between the leaves of books. These flowers, it will be remembered, are above 3000 years old, and their preservation is probably due to their having been buried in hot sand, a mode still in use in Palestine, by which means botanical specimens retain their colour for a long time unchanged, a process perhaps known to the ancient Egyptians, although wreaths and flowers, even of the Roman times, from Egypt are brown and semicarbonised. The tomb of Amenophis I. is mentioned as at the Drah Abu-el-Neggah in the Abbot Papyrus, and the body transported thence of Thothmes I., his son; the mummy case, considerably mutilated, was only found, and this had been appropriated by Pinotem. The mummy of Thothmes II., in three mummy cases, was likewise discovered. That of Thothmes III., the great and warlike monarch of the eighteenth dynasty, was found in a single coffin much mutilated, his body broken into three pieces and rifled in ancient times, but with an inscribed ritualistic linen roll said to prove the identity of the mummy. Of the other personages of the eighteenth dynasty were the mummies and coffins of the Prince Saamen, the Princess Satamen, a princess and king's sister, but unmarried, named Hanta-em-hu; and a similar royal sister and queen named Me-han-ta-emhu, child of Hanta-ena-hu, had been removed at the time of the twenty-first dynasty; another unmarried queen-sister named. Miramen, and Nebseni, a priest or flamen of a Pharaoh. All these coffins of the eighteenth dynasty have a certain similarity with each other. Those of the nineteenth are Rameses I., whose tomb and sarcophagus are at the Biban-el-Molook. There is some uncertainty in the different accounts which have come to hand whether there are three coffins or one, and if the mummy was deposited at the Deir-el-Bahari. The mummy of Seti I., whose tomb is in the Biban-el-Molook and alabaster sarcophagus in the Soane Museum of London, is well preserved in one wooden coffin; the mummy of one of the Ramessids, apparently the twelfth, not the second, as reported, in a plain coffin, the features not aquiline, but the shroud, covered with lotus flowers, looking remarkably fresh; this also came from the Biban-el-Molook. These mummies, it is stated, were removed under apprehension of a foreign invasion. Then follow the cases and mummies of the twenty-first dynasty. The queen, Notem, mother or wife of Herhor, of whom there is a papyrus in the British Museum, exhibited by H.R.H. the Prince of Wales, in a badly-preserved but inlaid coffin; Panotem or Pinotem, high-priest of Amen, in three coffins of the style called rich $i$ by Marriette, and gilded faces; he was, besides high-priest, a saten sa Kush, Prince of Cush or Ethiopia, according to the inscription in Lepsius' Königsbuch; the queen, Ramaka or Makarra, who assumed the same prenominal title as Hatasu of the eighteenth dynasty, who is in three coffins with the youthful queen, called the "lady of the two countries," or absolute queen-heiress, embalmed in a sitting posture, either having died in a fit or at her birth, and named Mutemhat ; the king, Pinotem II., hastily, deposited in the coffins of Thothnes I., the mummy has been partially unwrapped and the features exposed, which have a singular resemblance to those of Voltaire, with a sarcastic or satiric smile or grin, a peculiarity also found on a hieratic papyrus ritual in the British Museum, probably of the same period; the queen-mother, Hantau, whose ritual had found its way to the Boolak Museum prior to the discovery; in three cases, the prince Masaharuta, son of Pinotem II. in the same; the queen Asemkheb or Hesemkheb, in as many cases, who appears to have been the wife of Menkheperra; another princess called Nasikhonsu; Tet-ptahaufankha in an appropriate coffin, and four other priests and functionaries. Several other objects were found in the pit : a leather tent embroidered with names, boxes with royal names, boards with inscriptions, and five rituals of the monarchs of the later dynasty; but the whole of the details-amulets, inscriptions, and style of art-cannot be known until the mummies are unrolled and all peculiarities carefully examined, for this remarkable find will afford invaluable data for Egyptian archæology, especially the sepulchral division.

\section{TWO SPIDER BOOKS}

The Spiders of Dorset, with an Appendix containing Descriptions of those British Species not yet found in Dorsetshire. By the Rev. Octavius Pickard-Cambridge, M.A., C.M.Z.S., \&c. From the Proceedings of the Dorset Natural History and Antiquarian Field Club, edited by Prof. James Buckman. (Sherborne : L. H. Ruegg, pp. I-625, with 6 plates, I879- I88I, 8vo.)

Studi sui Ragni malesi e papuani. Per T. Thorell. III. Ragni dell' Austro-Malesia e del Capo York, conservati nel Museo Civico di Storia Naturali di Genoa. Pp. I-720. 8vo. (Genoa, I88r.)

T $F$ we take down part 2 of vol. i. of the twelfth edition 1 of Linnés "Systema Naturæ" (1767) and refer to that marvellously incongruous order Aptera, in which the 